\title{
Corm damage caused by banana weevils Cosmopolites sordidus (Germar) collected from different banana growing regions in Uganda
}

Charles K. Twesigye ${ }^{1 *}$, Kenneth Ssekatawa ${ }^{1}$, Andrew Kiggundu ${ }^{2}$, Wilberforce Tushemereirwe ${ }^{2}$, Enock Matovu ${ }^{3}$ and Eldad Karamura ${ }^{4}$

\begin{abstract}
Background: In this study, both healthy tissue culture plantlets and maiden suckers of the Nakitembe cultivar were used to assess the damage level variation caused by banana weevils collected from different banana growing regions. Seventy-nine (79) tissue culture plantlets and fifty (50) suckers were established in buckets in a randomized complete block design for 5 months. Ten adult weevils ( 5 females and 5 males) were introduced at the base of each plant, and the buckets were covered with a weevil proof mesh. Weevil damage was estimated as a percentage at 60 days after the weevil introduction by estimating the peripheral damage (PD), total cross section corm damage (XT) and above the collar damage (ACD).

Results: The results showed high differences in the PD, XI, XO and XT caused by weevils from the different zones. PD and XT ranged from 4.8-50.4 to 4.2-43.8\%, respectively, caused by weevils collected from Kabale and Rakai, Kabale and Wakiso, respectively, while XI and XO varied from 0.0-42.9 to 8.3-40.4\%, respectively, caused by banana weevils collected from Kabale and Rakai, Kabale and Rakai, respectively. Banana weevils from Rakai caused the highest ACD of $40.4 \%$ and no such damage was caused by banana weevils collected from western Uganda. Average ACD in suckers was $19.6 \%$ and significantly higher than that in tissue culture plants (8.5\%).
\end{abstract}

Conclusions and recommendations: Corm damage assessment suggests the existence of banana weevil biotypes but it is recommended that follow-up studies be carried out to confirm this phenomenon.

Keywords: Variation, Banana weevil, Corm damage

\section{Background}

The banana weevil Cosmopolites sordidus (Germar) is the most challenging insect pest of Musa spp globally. In most regions of East Africa, the East African highland banana (EAHB) (Musa sp. AAA) is the staple food crop mainly produced by subsistence farming, while plantain (Musa spp. AAB) is a significant staple in much of West and Central Africa [1, 2]. Uganda produces

\footnotetext{
*Correspondence: twesigyeck@yahoo.com

${ }^{1}$ Department of Biological Sciences, Faculty of Science, Kyambogo

University, P.O. Box 1, Kyambogo, Kampala, Uganda

Full list of author information is available at the end of the article
}

approximately 9.2 million metric tons annually hence making it the second leading banana producer in the world with the highest per capita consumption that is estimated at $450 \mathrm{~kg} /$ person/year [3, 4]. The EAHB is used to make a dish branded matooke in Uganda and is mainly grown for consumption and as a source of rural income which offers the best profits to family labor $[5,6]$. Both EAHB and Musa spp. AAB banana cultivars are highly susceptible to the banana weevil $[1,2]$.

Highland cooking (Musa AAA-EA) and beer bananas (Musa AAA-EA, ABB and AB) comply the most important staple food crop for the East African Great Lakes region. The fruit is consumed on farm, sold in local 
markets or transported by traders to urban centers. An extended harvest period ensures food and income sources throughout the year. Highland bananas reduce soil erosion on steep slopes and are principal sources of mulch for maintaining and improving soil fertility. East Africa represents a secondary center of crop diversity, while highland cooking cultivars are unique to the region (Stover and Simmonds, [7].

Uganda is Africa's leading producer and consumer of bananas. In recent years, drastic yield declines in traditional banana growing areas such as Mpigi, Luwero, Mukono and Iganga districts have led to the replacement of cooking bananas with beer types and/or annual crops (e.g., cassava and sweet potatoes) (Karamura et al. [8]. Planting of annual crops necessitates frequent opening of the land, thereby accelerating soil erosion. In Uganda, as elsewhere in the region, banana production constraints include a pest complex (weevils, nematodes and diseases) which causes serious yield losses and shortened plantation life [9]). However, pest infestation levels are unknown and yield losses have been neither quantified nor partitioned among constraints. Farmers have identified weevils and deteriorating soil fertility as their most important problems but causal factors were frequently confused and damage by nematodes, and pathogens were often attributed to other factors (Gold et al. [9]).

However, each of the banana groups suffers from its own pest and disease constraints. For example, banana weevils and nematodes are highly damaging to highland cooking banana and plantain production, while Fusarium wilt is the key constraint to dessert bananas and $A B B$ and AAB brewing bananas (Sengooba [10]; Sebasigari and Stover [11]. Soil degradation, due to increasing pressure on the land, associated with socioeconomic factors, also reduces production. A combination of these factors has been blamed for the "banana decline"; mean production in this region has dropped steadily, from 10 (1970) to 4.5 t/ha on subsistence farms (Gold et al. [12], Karamura et al. [13], Okech et al. [14] Tinzaara et al. [15]). This has had a negative effect on both food and household income security for local populations. Yet, research results in the region indicate that $30-40 \mathrm{t} / \mathrm{ha}$ can be obtained.

The decline in production and total destruction of highland banana in central Uganda and western Tanzania was attributed to banana weevils and consequently included the banana weevil among the principal limiting factors of banana production in East Africa $[16,17]$. Eggs are laid by the female into the corm and pseudostem base of the banana plant and the resultant larvae tunnel through the corm hence damaging it. This hampers water and nutrient uptake as well as weakening the plant anchorage into the soil. Therefore, banana weevil attack can interfere with crop establishment, reduce bunch size, result in toppling plants, lead to mat dying-out and shortened plantation life $[2,16,18]$.

Presently, there is no single control strategy that offers absolute control for banana weevils. Therefore, integrated pest management (IMP) strategy combining an array of methods such as habitat management (cultural control), biological control, host plant resistance, botanicals, and in some cases application of pesticides was deemed effective in the control of banana weevils [19]. Pesticides have been widely used by farmers but they are not highly recommended because of their broad spectrum, high cost and possibility of banana weevils developing resistance as a result of overuse $[16,17]$. Therefore, the most promising control strategy in integrated pest management is host plant resistance to banana weevils which offers the potential to provide long term and sustainable crop protection to subsistence farmers at little cost [20]. Unfortunately, development of resistant cultivars through conventional breeding has resulted into hybrids with undesirable cooking traits since the majority of resistant cultivars are non cooking types presenting a problem to breeders, as cooking types are staple because of consumer preference [21]. Therefore, host plant resistance without altering the cooking traits of the staple cooking bananas can be achieved by breeding genetically modified plants which are resistant to banana weevils.

However [22], using Random Amplified Polymorphic DNA (RAPD), reported existence of banana weevil biotypes in Uganda. This is supported by different yield losses caused by banana weevils in different banana growing regions. Total destruction of banana plantation in central Uganda and negligible losses in Western Uganda was documented [23, 24].

The main objectives of this study were to: (1) establish the variation in corm damage caused by banana weevils collected from different banana growing regions in potted experiments under the same environmental conditions and (2) provide an insight into the existence of banana weevil biotypes that are essential in screening banana plants resistant to weevils.

\section{Methods}

\section{Site description and source of materials}

This study was carried out at National Agricultural Research Laboratories, Kawanda, situated at $0^{\circ} 25^{\prime} \mathrm{N}$, $32^{\circ} 32^{\prime} \mathrm{E}, 1190 \mathrm{M}$ above sea level, $13 \mathrm{~km}$ north of Kampala. Nakitembe suckers used in this study were collected from the National Banana Research Program, Uganda, banana plantations, whereas Nakitembe tissue culture plantlets were obtained from the Tissue Culture Laboratory at the National Agricultural Research Laboratories, Kawanda. Nakitembe was the cultivar of choice in this study, because Nakitembe tissue culture plantlets 
were available at an advanced stage in the Tissue Culture Laboratory. Before being used in potted experiments, sucker corms were pared and the entire pared corm was immersed in boiling water for $1 \mathrm{~min}$ to ensure that they were completely free from the weevils [25].

\section{Sources of banana weevil}

Weevils were captured from farmers' banana plantations in the districts of Kabale, Ntungamo, Mbale/Sironko, Wakiso, Rakai, Bushenyi/Mbarara, Masaka, Kabarole (Fortportal) and Mukono using pseudostem traps on the basis of a grid map produced for diagnostic surveys of banana-based cropping systems [26].

\section{Maintenance of weevils}

Banana weevils were reared in an entomology laboratory in perforated plastic containers at room temperature. They were maintained on fresh Mbwazirime cultivar corm pieces that were changed regularly to avoid building up of rotting corm materials. All the test weevils were kept in these containers for at least 1 month before use in the experiments for acclimatization, and they were sexed using methods described by [27] whereby weevils were observed using a hand lens and males were differentiated from females on the basis of punctuations on their rostrums spreading beyond the point of antennae insertion.

\section{Corm damage assessment experimental design}

Seventy-nine (79) Nakitembe tissue culture plantlets and fifty (50) Nakitembe corms were planted in twenty liter perforated buckets with sterile soil mixed with farm yard manure and left to establish in a randomized complete block design with adequate watering for 5 months. The number of tissue culture plantlets and corms used was different due to their availability. Furthermore, the number of banana plants challenged with weevils was determined by the availability of weevils collected from each district as shown in Table 2. After 5 months, five adult female and five adult male weevils which were previously reared in an entomology laboratory were put in each of the ninety-six (96) buckets after which they were enclosed by a weevil proof net to prevent escape or entry of foreign weevils. The remaining thirty-three (33) plants were not challenged with weevils and therefore used as control. The plants were uprooted 2 months after introduction of the weevils. Roots were peeled off the corm, and peripheral damage (PD) was determined by estimating the percentage corm surface damage (Fig. 1).

A cross section of the corm was made $1 \mathrm{~cm}$ below the collar to determine the upper inner cross section damage, UXI (upper inner cylinder damage) and upper outer cross section damage UXO (upper cortex damage) by estimating the percentage damage of the upper inner cylinder region and upper cortex region, respectively (Fig. 2). A second cross section was made $3-5 \mathrm{~cm}$ depending on the size of the corm below the first cross section to determine the lower inner cross section damage, LXI (lower inner

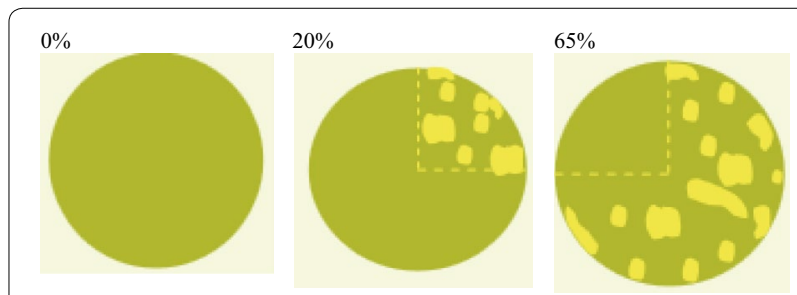

Fig. 2 Diagrams illustrating estimation of percentage cross section circumference corm damage

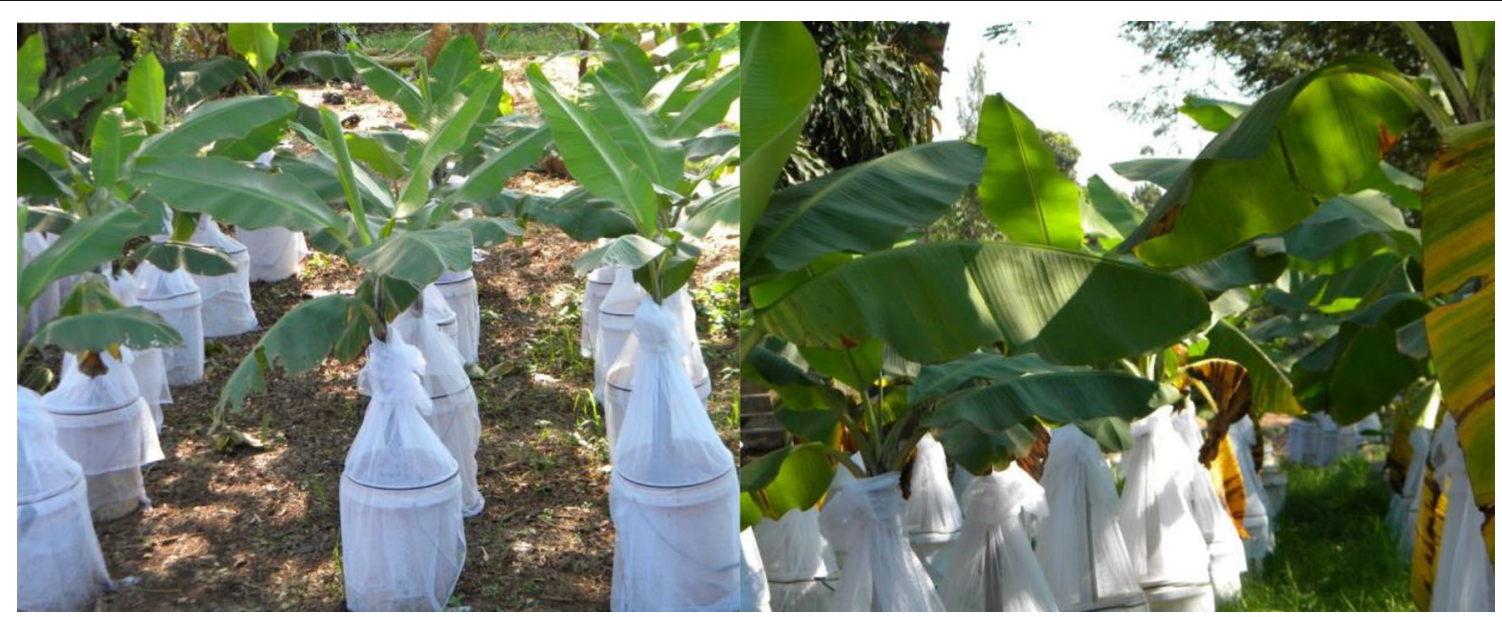

Fig. 1 Potted banana plants wrapped in buckets after introducing adult weevils 
cylinder damage), and lower outer cross section damage, LXO (lower cortex damage), by estimating the percentage damage of the lower inner cylinder region and lower cortex region, respectively. Percentage corm damage was estimated by dividing the corm exposed cross section surface into four equal quarters. Area covered by galleries in each quarter was approximated out of $25 \%$. Percentage cross section damage per corm circumference was computed by summing the percentage damage in all the four quarters.

The upper outer cross section damage UXO was added to the lower outer cross section damage LXO, and the mean was calculated to get the percentage total outer cross section damage XO. The average percentage of the upper inner cross section damage (UXI) and the lower inner cross damage (LXI) was calculated to acquire the percentage total inner cross section damage XI. The average of total inner cross section damage XI and total outer cross section damage $\mathrm{XO}$ was established to attain the percentage total cross section damage XT. A cross section. $0.1 \mathrm{~cm}$ above the collar region was made to determine the above collar damage, ACD, by estimating the percentage damage on the cut section.

This experiment was repeated once to compare the results, and collected data were transformed using Arcsine transformation method to reduce the non-normality and heterogeneity of variance before the means were separated. The transformed data were subjected to analysis of variance (ANOVA) using the general linear model (GLM) on a Statistical Analysis Software (SAS) (v.9.2; SAS Institute [28], and the means for corm damage generated were separated using Student-Newman-Keuls test at $5 \%$ level of significance.

\section{Results}

Evaluation of corm damage caused to banana plants established from tissue banana plantlets and suckers Mean percentages of $\mathrm{PD}, \mathrm{ACD}, \mathrm{XI}, \mathrm{XO}$ and $\mathrm{XT}( \pm \mathrm{SE})$ for both tissue culture plants and suckers were compared, and the results showed no significant difference $(p \leq 0.05)$ in PD, XI, XO and XT levels caused both to tissue culture plant and suckers but ACD level caused was significantly different $(p \leq 0.05)$ between tissue culture plants and suckers as displayed in Table 1 . However, in general, all the different damage types were higher in suckers than in tissue culture plants.

\section{Comparison of corm damage caused by banana weevils collected from the different banana growing regions} Mean percentage peripheral damage $(\mathrm{PD})( \pm \mathrm{SE})$ ranged from 4.8 to $50.4 \%$ and 0.0 for control. PD caused by weevils from Rakai and Fortportal was higher than PD caused by weevils from Masaka, Wakiso, Mukono, Sironko, Mbarara, Ntungamo, Mbale and Kabale. Student-Newman-Keuls test rankings indicate insignificant difference $(p<0.05)$ in PD caused by weevils from different sources as displayed in Table 2.

For mean percentage above collar damage (ACD) $( \pm \mathrm{SE})$, Student-Newman-Keuls test rankings indicate significant difference $(p>0.05)$ between ACD caused by weevils from Rakai, Wakiso, Mbale, Sironko, Masaka, Mukono and Kabale, Ntungamo, Fortportal, Mbarara and control as shown in Table 2. In general, there was no ACD caused by weevils collected from western Uganda.

There is no significant difference in cross section damage (mean percentage inner cross section damage (XI), outer cross section damage (XO) and total cross $\mathrm{XT}$ ) caused by weevils collected from different banana growing regions as indicated by the Student-Newman-Keuls test rankings in Table 2. However, the results showed high damage levels caused by weevils from central and southern Uganda and low damage levels caused by weevils collected from eastern and Southwest and Mid-west Uganda (Figs. 3, 4).

\section{Discussion}

\section{Corm damage variation}

The results of the study revealed that the damage types caused by banana weevils collected from different regions had slight differences. This study revealed that there is a significant difference in above the collar damage (ACD) caused by weevils collected from different banana growing regions. $\mathrm{ACD}$ is where banana weevil larvae and

Table 1 Mean percentage peripheral damage, PD, percentage above the collar damage, ACD, percentage inner cross section damage, XI, percentage outer cross section damage, XO and percentage total cross section damage, XT, based on plant type

\begin{tabular}{lllllll}
\hline Plant type & $\begin{array}{l}\text { No. of banana } \\
\text { plants }\end{array}$ & PD (\%) & ACD (\%) & XI (\%) & XO (\%) & XT (\%) \\
\hline Tissue culture & 79 & $23.0 \pm 3.6^{\mathrm{A}}$ & $8.5 \pm 1.5^{\mathrm{B}}$ & $18.3 \pm 3.1^{\mathrm{A}}$ & $19.9 \pm 2.6^{\mathrm{A}}$ & $19.1 \pm 2.7^{\mathrm{A}}$ \\
Sucker & 50 & $24.2 \pm 4.7^{\mathrm{A}}$ & $19.6 \pm 4.6^{\mathrm{A}}$ & $27.7 \pm 5.6^{\mathrm{A}}$ & $21.9 \pm 4.7^{\mathrm{A}}$ & $24.8 \pm 5.0^{\mathrm{A}}$ \\
\hline
\end{tabular}

Mean values in each column accompanied by the same letter are not significantly different $(p<0.05)$ (Student-Newman-Keuls test rankings) and values accompanied by letter (s) which are not similar are significantly different $(p>0.05)$ 
Table 2 Mean percentage peripheral damage, PD, percentage above the collar damage, ACD, percentage inner cross section damage, $\mathrm{XI}$, percentage outer cross section damage, $\mathrm{XO}$ and percentage total cross section damage, $\mathrm{XT}$, caused by banana weevils from different regions

\begin{tabular}{lllcccc}
\hline Weevil source & $\begin{array}{l}\text { No. of banana } \\
\text { plants }\end{array}$ & PD (\%) & ACD (\%) & XI (\%) & XO (\%) & XT (\%) \\
\hline Rakai & 16 & $50.4 \pm 09.0^{\mathrm{A}}$ & $40.4 \pm 6.9^{\mathrm{A}}$ & $42.9 \pm 9.7^{\mathrm{BA}}$ & $40.4 \pm 7.6^{\mathrm{A}}$ & $41.7 \pm 8.4^{\mathrm{BA}}$ \\
Kyenjojo & 05 & $50.0 \pm 12.2^{\mathrm{A}}$ & $0.0 \pm 0.0^{\mathrm{C}}$ & $23.5 \pm 7.9^{\mathrm{BA}}$ & $36.2 \pm 11.1^{\mathrm{BA}}$ & $29.9 \pm 9.0^{\mathrm{BAC}}$ \\
Masaka & 15 & $39.0 \pm 08.7^{\mathrm{AB}}$ & $10.4 \pm 5.1^{\mathrm{BC}}$ & $34.0 \pm 9.5^{\mathrm{BA}}$ & $31.4 \pm 7.6^{\mathrm{BA}}$ & $32.7^{\mathrm{B}} \pm 8.0^{\mathrm{BAC}}$ \\
Wakiso & 12 & $38.4 \pm 10.3^{\mathrm{AB}}$ & $31.9 \pm 7.2^{\mathrm{AB}}$ & $51.2 \pm 11.6^{\mathrm{A}}$ & $36.4 \pm 9.5^{\mathrm{BA}}$ & $43.8 \pm 10.1^{\mathrm{A}}$ \\
Mukono & 07 & $30.7 \pm 06.1^{\mathrm{AB}}$ & $9.3 \pm 4.9^{\mathrm{BC}}$ & $37.0 \pm 8.4^{\mathrm{BA}}$ & $37.2 \pm 8.3^{\mathrm{BA}}$ & $37.7 \pm 8.3^{\mathrm{BAC}}$ \\
Sironko & 12 & $27.6 \pm 10.0^{\mathrm{AB}}$ & $11.3 \pm 6.4^{\mathrm{BC}}$ & $11.8 \pm 4.8^{\mathrm{BA}}$ & $12.6 \pm 3.2^{\mathrm{BA}}$ & $12.2 \pm 3.7^{\mathrm{BAC}}$ \\
Mbarara & 06 & $23.3 \pm 12.8^{\mathrm{AB}}$ & $0.0 \pm 0.0^{\mathrm{C}}$ & $18.7 \pm 9.8^{\mathrm{BA}}$ & $23.2 \pm 8.2^{\mathrm{BA}}$ & $20.9 \pm 8.5^{\mathrm{BAC}}$ \\
Ntungamo & 07 & $20.7 \pm 10.3^{\mathrm{AB}}$ & $0.0 \pm 0.0^{\mathrm{C}}$ & $19.0 \pm 9.4^{\mathrm{BA}}$ & $18.6 \pm 7.8^{\mathrm{BA}}$ & $18.8 \pm 8.3^{\mathrm{BAC}}$ \\
Mbale & 10 & $13.1 \pm 07.5^{\mathrm{AB}}$ & $21.1 \pm 9.0^{\mathrm{ABC}}$ & $10.8 \pm 10.0^{\mathrm{BA}}$ & $8.8 \pm 6.9^{\mathrm{BA}}$ & $9.8 \pm 8.4^{\mathrm{BAC}}$ \\
Kabale & 06 & $4.8 \pm 03.8^{\mathrm{AB}}$ & $0.0 \pm 0.0^{\mathrm{C}}$ & $0.0 \pm 0.0^{\mathrm{B}}$ & $8.3 \pm 0.8^{\mathrm{BA}}$ & $4.2 \pm 3.4^{\mathrm{BC}}$ \\
Control & 33 & $0.0 \pm 0.0^{\mathrm{B}}$ & $0.0 \pm 0.0^{\mathrm{C}}$ & $0.0 \pm 0.0^{\mathrm{B}}$ & $0.0 \pm 0.0^{\mathrm{B}}$ & $0.0 \pm 0.0^{\mathrm{C}}$ \\
\hline
\end{tabular}

Mean values in each column accompanied by the same letter are not significantly different $(p<0.05)$. (Student-Newman-Keuls test rankings) and values accompanied by letter (s) which are not similar are significantly different $(p>0.05)$

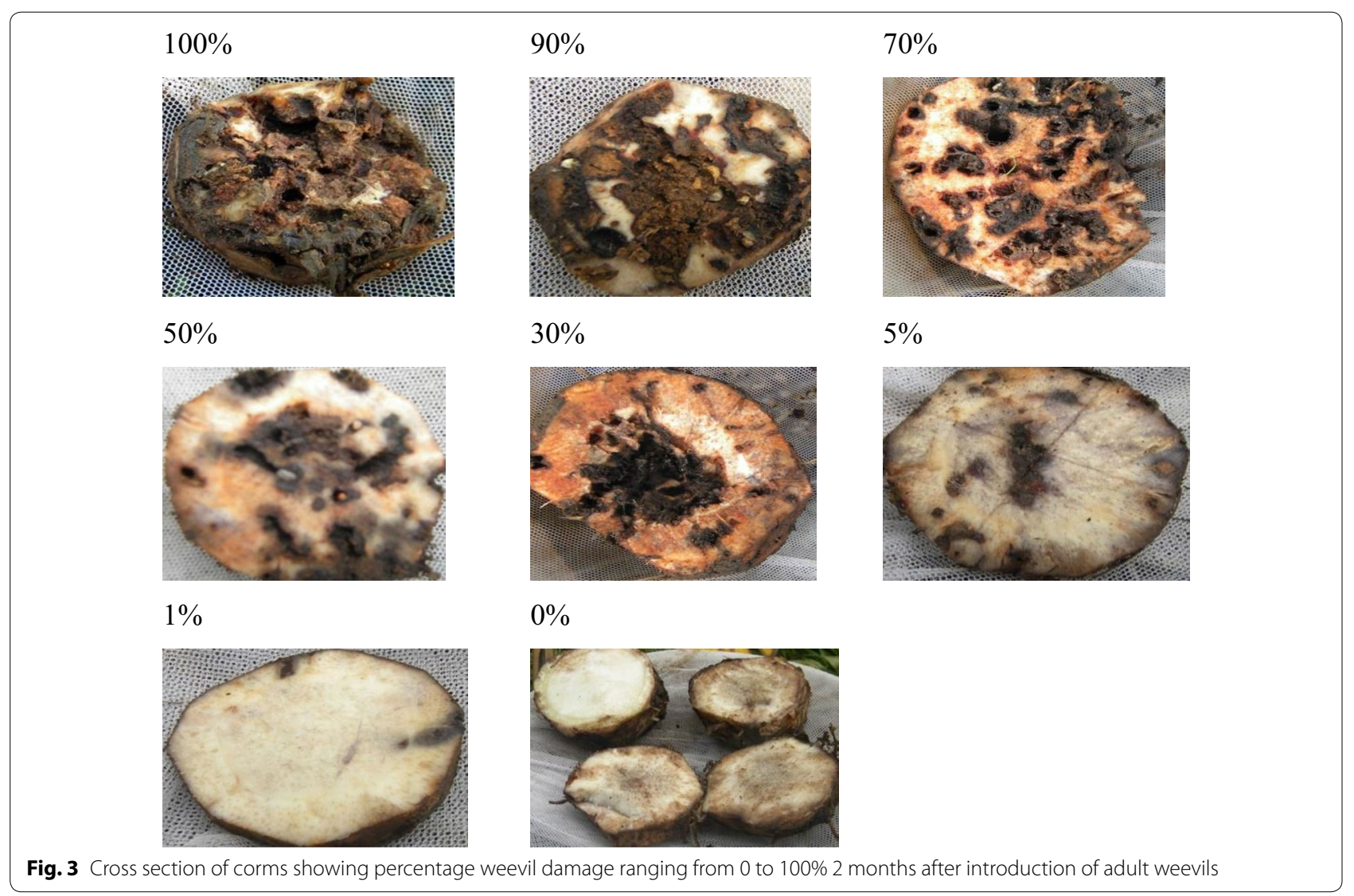

adults bore in a region immediately above the corm, and it is a rare case which has not yet been studied. It is interesting to note that ACD clusters the weevils into two main populations; the western (Mid-west and Southwest regions) Uganda population (Kabale, Ntungamo, Mbarara/Bushenyi and Kyenjojo) and central, south and eastern Uganda population (Masaka, Rakai, Wakiso, Mukono, Mbale and Sironko). 

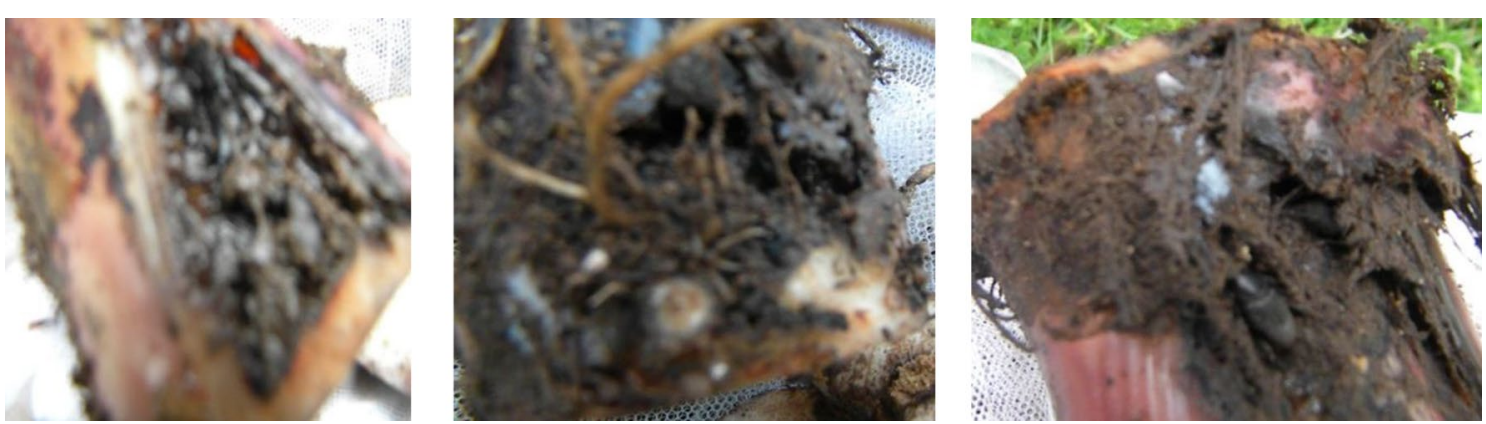

Fig. 4 Representative banana pseudostems showing above the collar damage caused by banana weevil collected from different sites

The results showed that there are low peripheral damage (PD), low total cross section damage (XT) and no ACD caused by weevils from western Uganda and this explains why the yield loss caused by banana weevils in western (Mid-west and Southwest regions) Uganda is negligible. The report [20] is in agreement with these findings. Western region had the highest yield of banana in Uganda at 6.0 metric tons/hectare, whereas banana weevils collected from central (Wakiso and Mukono) and southern Uganda (Masaka and Rakai) caused significantly very high ACD as compared to the weevils from western Uganda (Mid-west and Southwest regions).

Since XT measures the extent to which the larvae could penetrate deep into the corm, internal corm damage directly affects the yield and survival of the banana plant [12], therefore, high ACD and XT caused by banana weevils collected from central and southern (Central and South regions) Uganda in pot experiments provide an insight into why banana weevils caused a yield loss of $20-60 \%$ in the central and up to $100 \%$ in southern Uganda as reported by $[15,30]$. This is supported by the report [29] which showed that central Uganda had the lowest yield in metric tons/hectare $(3.3 \mathrm{M} \mathrm{t} / \mathrm{Ha})$.

Weevils collected from eastern Uganda caused high ACD second to that of central and southern Uganda but not significantly different while significantly different from that caused by weevils from western (Mid-west and Southwest regions) Uganda. Follow-up field visits in a natural setting showed high level of ACD in Rakai district.

Relatively high ACD but the lowest inner cross section damage (XI), outer cross section damage (XO) and $\mathrm{XT}$ support the fact that no much yield loss due to banana weevils has been reported in the districts of Mbale, Sironko and Kapchorwa. This is evidenced by the eastern region ranking the second producers of banana in Uganda in metric tons/hectare at 5.6 $\mathrm{M} \mathrm{t} / \mathrm{Ha}$ [29].

The variation in the corm damage levels caused by banana weevils collected from different banana growing regions in potted experiments supports the existence of banana weevil biotypes. However, earlier studies associate dissimilarities in corm damage levels to difference in environmental conditions. [17, 22, 23] observed that the mean fraction weevil damage was greater in Masaka than in Bushenyi. They attributed this difference to variation in temperature as a result of altitude.

This indicates that banana growing regions on higher altitudes (Eastern, Western, Mid-west) are less affected by banana weevils compared to those found on lower altitudes (central and southwestern) because areas on higher altitude experience low environmental temperature which does not support high rate banana weevil growth [30]. The results showed no significant difference $(p \leq 0.05)$ in PD, XI, XO and XT levels caused both to tissue culture plant and suckers but ACD level caused was significantly higher in suckers than in tissue culture plantlets.

All the different damage types were higher in suckers than in tissue culture plants because tissue culture corms are too small to support many banana weevil larvae. The larvae exhibit cannibalism [31] and when they happen to meet they feed on each other hence reducing on the larvae load in tissue culture plantlet corms and therefore lower percentage damage than the larger corms. Suckers possess very big corms supporting a large number of banana weevil larvae. The chances of these larvae meeting are minimal. Large number of larvae in a corm results in higher percentage damage in suckers.

\section{Conclusions}

Corm damage assessment revealed that banana weevils from eastern, central and southern Uganda cause more damage than those from Southwestern and Mid-west Uganda in potted experiments. Therefore, corm damage assessment study has provided methodologies for further studies like evaluating the resistance of genetically modified banana plants to banana weevils. Other physiological and behavioral studies should be carried out such as 
response to sex hormones (pheromones), pesticide resistance and life cycle tables to support the molecular work already done.

\section{Authors' contributions}

$\mathrm{KS}, \mathrm{AK}$, EK and CT designed the study, KS conducted the experiments, KS, AK and CT analyzed the data, KS and CT wrote the manuscript. All authors read and approved the final manuscript.

\section{Author details}

${ }^{1}$ Department of Biological Sciences, Faculty of Science, Kyambogo University, P.O. Box 1, Kyambogo, Kampala, Uganda. ${ }^{2}$ Uganda National Banana Research Programme, National Agricultural Research Laboratories, Kawanda, P.O. Box 7065, Kampala, Uganda. ${ }^{3}$ College of Veterinary Medicine Animal Resources and Biosecurity, CoVAB, Makerere University, P.O. Box 7062, Kampala, Uganda. ${ }^{4}$ Coordinator Bioversity International East and South Africa, P.O. Box 24384, Plot 106, Katalima Road, Naguru, Kampala, Uganda.

\section{Acknowledgements}

The authors would like to thank Bioversity International for funding the research and National Agricultural Laboratories Kawanda for providing laboratory facilities and office space to KS

\section{Competing interests}

All authors declared that they have no competing interests.

\section{Availability of data and materials}

All data generated or analyzed during this study are included in this published article (and its additional files).

\section{Consent for publication}

Not applicable.

\section{Ethics approval and consent to participate}

Not applicable.

\section{Funding}

This project was funded by Bioversity International through the National Banana Research Programme.

\section{Publisher's Note}

Springer Nature remains neutral with regard to jurisdictional claims in published maps and institutional affiliations.

Received: 11 October 2017 Accepted: 5 October 2018

Published online: 19 October 2018

\section{References}

1. Kiggundu A, Vuylsteke D, Gold CS. Recent advances in host plant resistance to banana weevil, Cosmopolites sordidus Germar. Mobilizing IPM for sustainable banana production in Africa. In: Frison E, Gold CS, Karamura EB, Sikora RA, editors. Proceedings of a workshop on banana IPM held in Nelspruit, South Africa, 23-28 November 1998. Montpellier: INIBAP; 1999. p. 87-96

2. Gold CS, Pinese B, Pena JE. Pests of banana. In: Pena JE, Sharp J, Wysoki M, editors. Pests and pollinators of tropical fruit. Wallingord: CABI Int; 2002. p. 13-56.

3. FAOSTAT. (2012). The Agricultural production. FAO.

4. Gertrude N, Gold SC, Alison G. Survivorship and development rates of banana weevils reared on excised plant material of different banana cultivars. Int J Trop Insect Sci. 2010;30:77-83.

5. Bagamba F. Resource allocation efficiency in a banana based cropping system in Uganda. M.Sc. thesis Makerere University, Kampala; 1994. p.116.

6. Embrechts J, Bananuka JA, Couveur, Y, Bagamba F. Banana sub-sector review, Republic of Uganda. (STABEX), Service Contract No. SCI26196; 1996.

7. Stover RH, Simmonds NW. Bananas. 3rd ed. London: Longmans; 1987.
8. Karamura E, Gold CS, Speijer PR, Tushemereirwe W. Banana pests and diseases in Uganda: historical perspective and research thrusts. In: Proceedings of the first annual crop science conference, 14-18 June 1993, Kampala, Uganda; 1994

9. Gold CS, Ogenga-Latigo MW, Tushemereilwe MW, Kashaija LN Nankinga C. Farmer perceptions of banana pest constraints in Uganda: results from a rapid rural appraisal. In: Gold SS, Gemmel B, editors. Proceedings of a research; coordination meeting for biological and integrated control of highland banana pests and diseases in Africa. Cotonou. 1214 November 1993; 1993

10. Sengooba T. Survey of banana pest problem complex in Rakai and Masaka districts, August 1986: preliminary trip report. Ministry of Agriculture, Namulonge Research station, Uganda. Unpublished; 1986. p. 10.

11. Sebasigari K, Stover RH. Banana diseases and pests in East Africa: report of a survey in November 1987. Montpellier: INIBAP; 1988.

12. Karamura EB, Frison EA, Karamura DA, Sharrock S. Banana production systems in eastern and southern Africa. In: Picq C, Fouré E, Frison EA, editors. Bananas and Food Security. Les productions bananières: un enjeu économique majeur pour la sécurité alimentaire. Proceedings of an international symposium held in Douala, Cameroon, 10-14 November 1998, France. Montpellier: INIBAP 1999. p. 401-412

13. Gold CS, Karamura EB, Kiggundu A, Bagamba F, Abera AMK. Geographic shifts in highland cooking banana (Musa spp., group AAA-EA) production in Uganda. Int J Sust Devel World Ecol. 1999;6:45-59.

14. Okech SHO, Karamura EB, Gold CS. Banana IPM in Uganda. In Mobilising IPM for Sustainable banana production in Africa (Frison EA, Gold CS, Karamura EB Sikora RA, editors. Proceedings of a workshop on banana IPM held in Nelspruit, South Africa, 23-28 November 1998; 1999. p. 225-236

15. Tinzaara W, Tushemereirwe W, Nankinga C, Kashaija I. Comparative studies on chemical, hot and cold-water treatments of banana suckers to control the banana weevil, Cosmopolites sordidus and the effect of paring suckers on banana nematodes in Uganda. Uganda J Agric Sci. 2002:7(2):43-7.

16. Mbwana ASS, Rukazambuga NDTM Banana IPM in Tanzania. In: Frison E, Gold CS, Karamura EB, Sikora RA, editors. Mobilizing IPM for sustainable banana production in Africa. Proceeding Workshop on Banana IPM held in Nelspruit, South Africa, 23-28 November 1998. Montpellier: INIBAP; 1999. p. 237-245

17. Rukazambuga ND, Gold CS, Gowen SR. Yield loss in East African highland banana (Musa spp., AAA-EA group) caused by the banana weevil, Cosmopolites sordidus (Germar). Crop Prot. 1998;17:581-9.

18. Gold CS, Peña JE, Karamura EB. Biology and integrated pest management for the banana weevil Cosmopolites sordidus (Germar) (Coleoptera: Curculionidae). Integr Pest Manag Rev. 2001;6:79-155.

19. Kiggundu A, Gold CS, Labuschagne MT, Vuylsteke D, Laow S. Levels of host plant resistance to banana weevil, Cosmopolites sordidus (Germar) (Coleoptera: Curculionidae), in Ugandan Musa germplasm. Euphytica. 2003;133:267-77.

20. Night G. Mechanisms and distribution of resistance to banana Weevil (Cosmopolites sordidus (Germar)) and the influence of plant nutrition on expression of resistance in banana. Cornell: Unpublished Graduate School of Cornell University; 2006

21. Ochieng VO. Genetic biodiversity in banana weevil Cosmopolites sordidus, populations in banana growing regions of the world. Ph.D. thesis, University of Nairobi, Kenya; 2001

22. Gold CS, Karamura E, Kiggundu A, Bagamba F, Abera AMK. Goegraphical shifts in the highland cooking banana (Musa spp group AAA-EA) production in Uganda. Int J Sustain Dev World Ecol. 1999;6:45-59.

23. Sein F Jr. Paring and heat sterilization of the corms to eliminate the banana root weevil Cosmopolites sordidus Germar. J Agric Univ Puerto Rico. 1934;18:411-6.

24. Gold CS, Speijer PR, Karamura EB, \& Rukazambuga ND. Assessment of banana weevils in East African highland banana systems and strategies for control. In: Proceedings of banana nematode/borer weevil conference, Kuala Lumpur, vol 18; 1994. p. 170-190

25. Longoria A. Dimorfismo sexual observado en pupas de Cosmopolites sordidus Germar (Coleoptera: Curculionidae). Ciencias Biológicas. 1968:6:1-6.

26. SAS. SAS/STAT users' guide version 9.2, SAS institute Inc, Cary NC US; 2008

27. Uganda Bureau of Statistics. Uganda Census of Agriculture 2008/2009. Crop area and production report: volume IV; 2010 
28. Gold CS, Night G, Speijer PR, Abera AMK, Rukazambuga ND. Infestation levels of banana weevil Cosmopolites sordidus (Germar) in banana plants established from treated propagules in Uganda. Afr Entomol. 1998;6:253-63.

29. Okech SHO, Karugaba A, Gold CS, Nyakuni A, Ssali H, Karamura E. Influence of soil conservation bands, compost manure, coffee and bean intercropping on weevil incidence, banana vigour and bunch weight in Bugamba subcounty, a hilly environment in Mbarara, south western Uganda. Afr Crop Sci Conf Proc. 1997;3:1221-8.
30. Mukasa HH, Ocan D, Rubaihayo PR, Blomme G. The influence of nematodes, weevils and management level on high mat, plant growth traits and yields in southwestern Uganda. In: Proceedings of the workshop on Farmer-participatory testing of IPM options for sustainable banana production in Eastern Africa, held in Seeta, Uganda, 8-9 December 2003; 2003

31. Gold CS, Kagezi GH, Night G, Ragama PE. Effects of banana weevil, Cosmopolites sordidus, damage on highland banana growth, yield and stand duration. Ann Appl Biol. 2004;145:263-9.
Ready to submit your research? Choose BMC and benefit from:

- fast, convenient online submission

- thorough peer review by experienced researchers in your field

- rapid publication on acceptance

- support for research data, including large and complex data types

- gold Open Access which fosters wider collaboration and increased citations

- maximum visibility for your research: over $100 \mathrm{M}$ website views per year

At BMC, research is always in progress.

Learn more biomedcentral.com/submissions 